Eulàlia Vernet i Pons

\title{
On the Latin Transcription of Hebrew and Aramaic Proper Names in the Latin Talmud (Tractate Sanhedrin). Phonetic Features of the Translation
}

DOI 10.1515/jtms-2015-0017

\begin{abstract}
The aim of this paper is to provide a linguistic and onomastic description of the proper names and other Hebrew biblical realia transcribed and translated into Latin in the Talmudic tractate of Sanhedrin (thirteenth century). The Latin translation of Sanhedrin is a part of the Talmudic corpus known as Extractiones de Talmud; it is the largest Latin translation of the Talmud and was produced in Paris by Christian theologians in the 1240s. While the Extractiones are a quite exhaustive translation of the Talmud, they are not complete, but offer a selection of different Talmudic tractates that were of theological interest in order to strengthen the Christian faith in a context of anti-Jewish polemic. An onomastic approach to the Latin Sanhedrin will allow us to describe philologically the Hebrew words underlying the Latin transcription. It will also give us information about the criteria of transcription followed by the Latin translators of the Talmud.
\end{abstract}

Keywords: Latin Talmud, Sanhedrin, onomastics, Hebrew language, Hebrew phonology

\section{Introduction}

The Latin translation of the Talmudic tractate Sanhedrin is part of a Talmudic corpus known as Extractiones de Talmud, the largest corpus of Latin Talmud translations, produced in Paris by Christian theologians in the 1240s. The discovery of this post-biblical Jewish corpus by Christian theologians was fundamental, both for refuting the Jewish faith and for sustaining the truth of Christianity. ${ }^{1}$

1 Regarding the place of the Talmud in medieval Christian Europe, see CHAZAN 2012; FIDORA 2014; FIDORA 2015c, p. 63-66. For the Jewish-Christian disputations in the Middle Ages, see, among

Corresponding author: Eulàlia Vernet i Pons, ERC Research Project 'The Latin Talmud and Its Influence on Christian-Jewish Polemic', Universitat Autònoma de Barcelona, Bellaterra, Spain, E-mail: eulalia.vernet@uab.cat 
The aim of this paper is to provide a general linguistic and onomastic description of the proper names and other Hebrew biblical realia transcribed and translated into Latin from the Talmudic tractate of Sanhedrin. The onomastic approach will allow us to describe philologically the underlying Hebrew terms through their Latin transcription. It will also give us information concerning the criteria of transcription followed by the Latin translators of the Talmud and it could help us in the future as a complementary tool to define codicologically the filiation of the Latin manuscripts. ${ }^{2}$

\subsection{The Babylonian Talmud as a 'Vorlage' for the Latin Translation. Language and Content}

As it is known, the structure and the contents of the Talmud is based on two textual corpora of diverse origin and epoch: ${ }^{3}$ the Mishnah ${ }^{4}$ and the Gemara (first to eighth centuries $\mathrm{CE}$ ), a comment on Mishnah, written in Aramaic and Hebrew. ${ }^{5}$ The Mishnah is considered by rabbinic Judaism as a Torah: it has therefore the same authority and canonization as the written Law. The Mishnah's canonization as an (oral) Torah is important for understanding how this text became an object of study and interpretation like the written Torah.

In Palestine and Babylon, the two most important centres of Judaism, two different comments on the Mishnah were written, giving way to the two main Talmudic corpora: the Jerusalem Talmud (first half of the fifth century) on the one hand, and the Babylonian Talmud (eighth century) on the other. Written at the academy of Sura (Babylon), the Talmud Bavli has comments on 36 treatises and a

others, MACCOBY 1982. Concerning the trial, condemnation and burning of the Talmud at Paris, see LOEB 1880-1881; DAHAN/NiCOLAS 1999; ROSE 2011; FRIEDMAN 2012a; FRIEDMAN 2012b; HOFF 2012. 2 With regard to the translators and the translation of the Latin Talmud in Paris, see FidORA 2015b.

3 The Talmud can be regarded as the main work of rabbinic literature. A grammatic and syntactic description of rabbinic Hebrew and Aramaic is found in PÉREZ FERNÁNDEZ 1992.

4 The text of the Mishnah (halakhic collection of Jewish religious laws completing and interpreting the Torah) was considered canonic by rabbinic Judaism for containing the oral Law. The language in which the Mishnah was written is known as rabbinic Hebrew I or Mishnaic Hebrew (still a living language). The rabbis of the Mishnah are known as "tannaim" (singular "tannâ", תנא).

5 The Gemara includes rabbinical discussions on the Mishnah. It was written in rabbinic Hebrew II (a dead language) and rabbinic Aramaic. The rabbis of the Gemara are called "amôraim" (singular “'amôrâ", אמורא). The Aramaic determined noun "gemarâ", literally 'study', 'memorizing of verbal teachings, tradition') derives from the semitic verbal root "*gmr-" (גמר), which in biblical Hebrew means 'to finish', whereas in rabbinic Aramaic it means specifically 'to know well', 'to be ready to answer' (JASTROW 1903, 1, p. 255 col. a and b). Regarding the question of 'orality' and 'textuality' during the geonic times, see FISHMAN 2011, p. 20-64. 
half among the 63 treatises contained in the Mishnah. ${ }^{6}$ The text of the Babylonian Talmud has been growing in concentric circles, with continuous reviews: because of its genesis and its oral transmission, it is not possible to find in it an 'Urtext', although one can identify different strata throughout its contents and its language (it is written in biblical and rabbinic Hebrew and in rabbinic Aramaic).

The research of the Latin Talmud Project allows us to confirm that the 'Vorlage' for the Latin translation of the Talmud was the Babylonian Talmud. Indeed, this is entirely natural, bearing in mind that the Talmud Bavli (and not the Talmud Yerushalmi) was the first Talmudic text to circulate in Europe and became the most widespread one. ${ }^{7}$

\subsection{Some Remarks on the Manuscripts Preserving the Latin Talmud}

The Latin translation of the Talmud Bavli prepared in Paris ca. 1244/1245 is preserved wholly or partially in at least eleven manuscripts. ${ }^{8}$ The classic literature on this

6 Talmud Bavli lacks those treaties that would have no more sense in Babylon (due to the fact of being out of Palestine and for having lost any hope for the new Temple). Besides the comment on the Mishnah, it compiles all sorts of legends ("midrashim"), stories about rabbis, issues in medicine, mathematics and astrology. The following division gives the six orders (Hebrew "sedarim") of the Mishnah, together with its tractates ("masektot"). Those tractates that were partially translated into

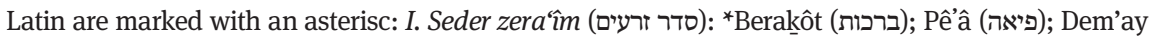

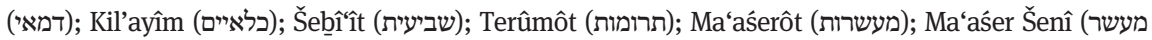

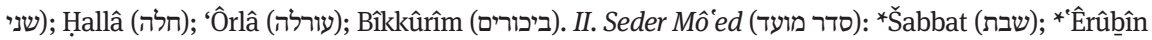

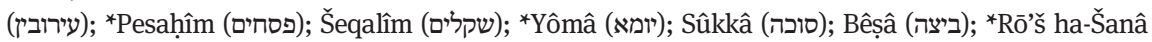

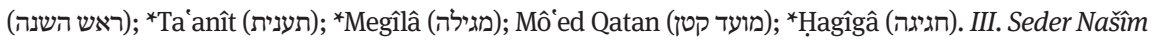
(סדר נשים): *Yebamôt (ניטות); ניבמות);

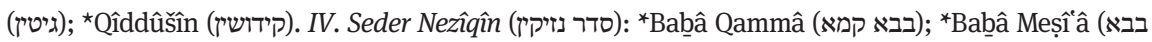

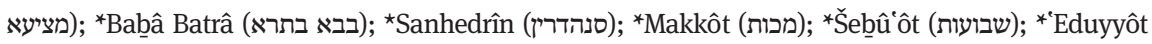

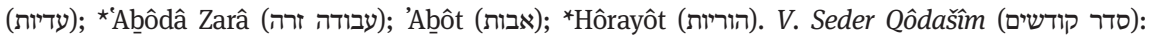
*Zebahịîm (זבחים); (מנחות); (מוליץ); (תמורה); *Kerîtôt (כריתות); Me îlâ (מעילה);

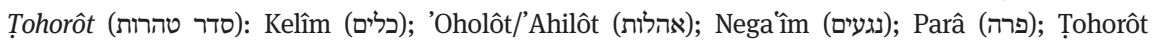

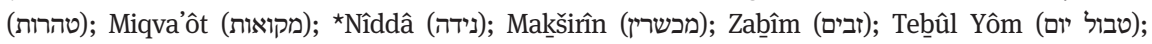
Yadayîm (ידים); 'Uqșin (מקציץ).

7 Regarding the copy of Talmudic manuscripts and its editions, see SIRAT 1990.

8 For these eleven manuscripts containing the Latin Talmud, see FIDORA 2015c, p. 66 sq., according to which, two manuscripts, P (Paris, Bibliothèque nationale de France, Ms. lat. 16558, thirteenth century) and Z (Paris, Bibliothèque Mazarine, Ms. 1115, end of the seventeenth century, a direct copy of P) offer the sequential and the thematic version. Other four manuscripts, i. e. W (Wrocław, Biblioteka Uniwersytecka, Ms. I Q 134 a, thirteenth century, fragment), G (Girona, Arxiu Capitular, Ms. 19b, fourteenth century, incomplete), C (Carpentras, Bibliothèque Inguimbertine, Ms. 153, fourteenth 
subject opined that the Paris manuscript (P) could be considered as a good representative of the Latin Talmud dossier, because it preserves more fully and clearly the set of documents related to the Extractiones de Talmud. ${ }^{9}$ This text was edited and transmited formally as a dossier, because after the Extractiones it has a set of texts including a thematic translation on Talmudic places - related to the history of this translation as well as some indices. ${ }^{10}$

From the textual point of view, according to Cecini, de la Cruz Palma and Vernet i Pons, the Paris manuscripts ( $\mathrm{P}$ and the codex descriptus $\mathrm{Z}$ ) are reliable, although it seems that the text has been corrected, in comparison with other testimonies that represent the translation of the text in the immediately preceding stage (as B and G, C). ${ }^{11}$ Regarding the three volumes of Firenze (F) transmitting the Babylonian Talmud in Hebrew, the second and third volumes translate in Latin as marginal notes the version of the Extractiones. These marginal glosses are older for their own textual characteristics than the translation transmitted by the Berlin

century) and B (Berlin, Staatsbibliothek Preußischer Kulturbesitz, Ms. Theol. lat. fol. 306, fifteenth century, incomplete), contain only the sequential version. The remaining four offer the thematic version, i. e. S (Schaffhausen, Ministerialbibliothek, Ms. Min. 71, thirteenth/fourteenth century), M (Stuttgart, Hauptstaatsarchiv, SSG Maulbronner Fragment, thirteenth/fourteenth century), Y (München, Bayerische Staatsbibliothek, clm 21259, thirteenth/fourteenth century, adapted short version) and L (London, British Library, Add. 19952, fifteenth century, adapted short version). To these Latin manuscripts, one can add the Latin marginal texts related to the Extractiones de Talmud appearing in volumes 2 and 3 of the Hebrew Talmud from Florence (Biblioteca Nazionale Centrale, Ms. II I, 7-9), which have been dated to the beginning of the fourteenth century. An edition of the Wrockaw manuscript was provided by KLAPPER 1926. For a description of manuscript G, see MILLÁS VALLICROSA 1960; FIDORA 2015b. An edition of the Maulbronn manuscript is provided by HASSELHOFF/DE LA CRUZ PALMA 2015. Regarding the Latin translations in the margins of the manuscript of Florence and the Latin Talmud, see MERCHAVIA 1965-1966; FIDORA 2015c, p. 67 with n. 16. For the Latin Talmud and the knowledge of this text in medieval Christendom, see among others KLIBANSKY 1933; FISHMAN 2011, p. 91-120. As far as the subject of Hebrew manuscripts in medieval Northern France is concerned, see SIRAT 1991.

9 LOEB 1880-1881; MERCHAVIA 1970.

10 The formal structure of this dossier is the following: 1a) fol. 1ra-96ra: Selective translation (thematic) of the Talmud with Praefatio in extractiones de Talmud. 1b) fol. 97ra-206rb: Extractiones de Talmud (sequential) with Praefatio in extractiones de Talmud. 1c) fol. 206rb-211rb: Liber Krubot. 2a) fol. 211rb-217vb: 35 articles from Nicolas Donin. 2b) fol. 217vb-224va: Talmudic anthology. 2c) fol. 224va-230vb: Anthology with glosses from Rashi. 2d) fol. 230vb-231va: Depositiones of the Rabbis Iehiel and Iehuda. 2e) fol. 231va-232va: A list with the names of Talmudic rabbis. 2f) fol. 232va-234va: Letters and official documents from Odo of Châteauroux and pope Gregory IX. 2g) fol. 234va-238vb: Bible index (other manuscripts offer subject indices or a hebraicum lexicon). For the two versions (sequential and thematic) of the Latin Talmud in connection with pope Innocent IV and his call for a revision of the decision of the Paris Talmud Trial from 1240, see FIDORA 2015c, p. 67.

11 CECINI e. a. 2015. 
manuscript (B): this fact gives us also further evidence that manuscript $\mathrm{P}$, considered as codex optimus, is the result of a correction process.

\section{On the Latin Transcription of Hebrew and Aramaic}

\subsection{Comments on the Latin Transcription in the Preface to the Extractiones}

With regard to the knowledge of Hebrew grammar and Masoretic punctuation in the thirteenth century, there are some interesting comments contained in the preface to the Extractiones that inform us about the level of knowledge of Hebrew language aquired by the Latin translator(s). ${ }^{12}$

\subsubsection{Masoretic Vowels}

The preface to the Extractiones tells us that the Hebrew language has six vowels, which are distinguished by diacritical marks (Paris, Bibliothèque nationale de France, Ms. lat. 16558, fol. 98rb): ${ }^{13}$

Et in hoc habent hebraei remedium, quia, cum sex punctorum differentias habeant pro sono vocalium, una earum in talibus servit eis, quae quasi inter '.e.' et '.eu.' medium habent sonum, sicut in gallico.

In addition to these full vowels, however, there are four extra short vowels, consisting in one simple "shwa mobile" (\$̣) or three "hatafim" (compound "shwaim"). ${ }^{14}$ Concerning the "shwa quiescens" and also concerning sonants and liquids in Hebrew, we find the following observation in the Latin preface to the Extractiones de Talmud (Paris, Bibliothèque nationale de France, Ms. lat. 16558, fol. 98rb-98va):

Ad hunc sonum forsitan pro nostra possibilitate formandum in quibusdam dictionibus post primam litteram vocalem non apponimus, sed quasi duas sillabas in unam coactamus,

12 For the knowledge of the Hebrew by Christians in medieval Europe, see ALTANER 1933. For the pronunciation of Hebrew language among the different languages in the Christian and Muslim kingdoms of the Iberian Peninsula, see Garbell 1954-1956; SARNA 1971, especially on the contribution of the Hebrew grammarians.

13 Masoretic Hebrew has the following vowels, differentiated from each other according to quality

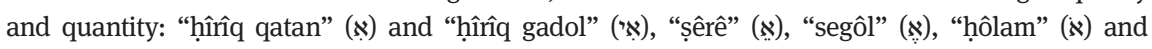

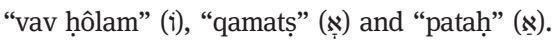

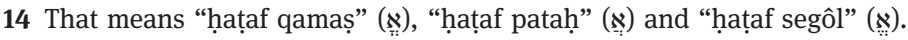


sicut in hiis: 'mna', 'bdellium', 'Smyrna', 'gnarus', 'Gnidum', 'pneuma' et similibus. Similiter crebro faciendum est in hebraeo, ut dicatur et scribatur: 'rby', 'Smuel', 'smay', id est 'audi', 'nozri', 'cenhezrim', 'mykra', et non: 'raby', 'samay', 'noceri', 'cenherym', 'mykara', et sic in similibus, quae quasi infinita sunt.

\subsubsection{Difficulties in Latin and Old French When Transliterating Hebrew Phonemes}

Likewise, this preface to the Extractiones echoes the difficulties that Latin and Old French people present when rigorously transliterating Hebrew phonemes in a vocalic context (Paris, Bibliothèque nationale de France, Ms. lat. 16558, fol. 98rb): ${ }^{15}$

Postremo sciendum est quod Latinarum defectus litterarum miram nobis difficultatem generat et quasi impossibilitatem scribendi gallicum et hebraeum, ut primas sillabas gallici istarum dictionum: 'venite', 'tenete', 'sedete' et similium, et ultimam harum: 'dominae', 'domina', 'dominam' et omnium huiusmodi, ita frequenter est in hebraeo.

But also regarding some sibilants and occlusives (Paris, Bibliothèque nationale de France, Ms. lat. 16558, fol. 98va): ${ }^{16}$

Est et alius litterarum nostrarum defectus: cum enim .c. littera cum .e. et .i. quasi 'blesum', habeat sonum et mollem, non potest eundem cum caeteris habere vocalibus; unde si velimus huius adverbii huc scribere gallicum, non .c. et .a. proprie sonabunt illud. Si gallicum harum dictionum: 'leccio', 'garcio' sive similium, ultima sillaba non bene scribitur per .c.o.n.; nec similiter prima sillaba gallici huius dictionis: 'noctua'. Nec media huius diccionis: 'clava' proprie per .c. et .v. scribi potest.

\subsection{The Latin Transcription of Biblical Proper Names}

As a result of transcribing names of biblical and rabbinic origin from Hebrew or Aramaic into Latin, we can get an idea of how classical and rabbinical Hebrew and Aramaic may have been read phonetically, despite the limitations of the

15 It is interesting that this preface does not echo explicitly the difficulties in transcribing in Latin the guttural consonants and also the emphatic consonants (a postglotalized series in protosemitic as well as in classical Ethiopic or Ge'ez) of Hebrew and all Semitic languages, having in mind that this consonantic feature does not exist in the consonant repertoire of Latin. 16 See also, regarding sibilants and plosive consonants, a similar explanation in the preface to the Extractiones de Talmud (Paris, Bibliothèque nationale de France, Ms. lat. 16558, fol. 98va/vb): "Quibusdam autem visum est in talibus loco .c. ponendum esse .th., et tunc .t. praepositum .a. et .o. et .u. sonandum est, sicut praepositum .i. alia uocali subsequente, ut in hiis dictionibus: 'lectio', 'scientia', 'rectius' et similibus, et ita scribendum: .tho., .tha., .thu., et sonandum est .c.: .tha., ut 'thazic' et 'thamec' litterae alphabeti hebraici, et 'Thatada', proprium nomen hominis; cum .o., ut 'asbamuthoz'; cum .u., sicut 'pathuc' et 'kthuym”'. 
Latin and the Romance languages in transcribing and articulating the phonemes of both Northwest semitic languages.

This section will analyze the main phonetic features of transcription concerning the Hebrew and Aramaic consonants (glottals, sibilants, plosives and dentals). Regarding the transcription of these Hebrew and Aramaic proper names into Latin, I would like to offer some observations. ${ }^{17}$

\subsubsection{Glottals}

\subsubsection{Glottal plosive “aleph” (')}

Regarding the glottal stops, the Latin translation of Sanhedrin, in order to mark the voiceless glottal plosive "aleph" ('), replaces this consonant by a zerophoneme or by a glottal fricative " $h$ ". It is interesting to note that the glottal stop "aleph" ( $)$ was in Ashkenazi Hebrew completely silent at all times. The same trend can be observed in the transcription of Hebrew word forms into Latin, preserved in the thirteenth-century Hebrew Bible from Ramsey Abbey. ${ }^{18}$ See the following examples:

“Heldad” (אֶלְדָד) [San. 17a(1)]:

This biblical proper name was transcribed also as "Helaad" or "Heldat" in some manuscripts ( $\mathrm{P}$ and $\mathrm{C}$ respectively). In Masoretic biblical Hebrew this anthroponym

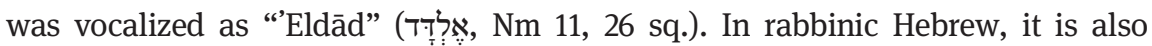
mentioned as "'Eldad" (Hebrew "'ldd", אלדד). given by manuscript $\mathrm{P}$, must be explained through the falling of the voiced dental "d" after a liquid "l", provoking a compensatory lengthening of the vowel: thus, "Heldad" < "Helād". It is also interesting to observe here the dissimilation regarding the original voiced " $d$ " into an unvoiced " $t$ " at the end of the word, a feature still present in some Romance languages and even possibly attributable to Old French.

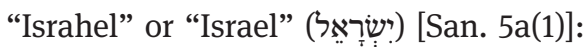

Biblical and rabbinic toponym. In biblical Masoretic Hebrew it was vocalized as

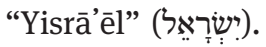

17 The editions of the Bible used in this paper are the following: For the "textus receptus masoreticus" of the Biblia Hebraica the edition by KARL ELLIGER and WILHELM RUDOLPH: Biblia Hebraica; for the Septuagint the edition by ALFRED RAHLFS: LXX; for the Latin Vulgata the edition by ROGER GRYSON e. a.: Vulgata. For the transcription of Hebrew words into Latin and Old French see DAHAN 2007, p. 249-258.

18 See Olszowy-Schlangen 2008, p. 1-4.

19 Heldad and Medad (Hebrew מידד) are two prophets cited in Nm 11, 26 sq. 


\subsubsection{Glottal fricative "hê" (ה)}

Regarding the proper names, the Hebrew unvoiced glottal fricative "hê" (ה) is not transcribed in the Latin transcription of Sanhedrin (zero-grapheme). Regarding this glottal consonant, see the following examples:

“Rab Iuda” (רב יהודה) [San. 22a(5)-22b(1)]:

This rabbi in the original passage of Talmud Bavli appears mentioned as "Rab Yehûdâ" (רב יהודה).

“Aaron” (אַהַ) [San. 7a(1)]:

In the Hebrew Bible and Talmud Bavli this proper name is "'hrn" (אהרן). In Masoretic biblical Hebrew it was vocalized as "'Ah"ron” (אָהָרן).

\subsubsection{Velar fricative "ḥet" (ח)}

As far as the Hebrew voiceless velar fricative "het" ( $\pi$ ) is concerned, the Latin translation of Sanhedrin usually transcribes this phoneme in three different ways: with a voiceless glottal fricative ("h"), with an "a" vowel or without any specific grapheme (Latin "zero"), as is shown by the following examples: ${ }^{21}$

Latin "h" (voiceless glottal fricative) instead of Hebrew velar fricative "ḥet” (ח) Note, again, that Hebrew voiceless velar fricative "het" is transcribed with a Latin unvoiced glottal fricative "h" ("Hur"), due to the absence of this Hebrew phoneme in Latin (and Old French):

"Rby Johan" (רבי יוחנן) [San. 17a]:

This rabbi is mentioned in the passage of the Babylonian Talmud as "Rabbi Johanan” (רבי יוחנן).

"Rby Nahamia” (רבי נחמיה) [San. 107b]:

In the Mishnah of Sanhedrin (107b) this proper name appears as "Rabbi Naḥamîâ" (רבי נחמיה).

"Hur” (חור) [San. 7a]:

In rabbinic Hebrew this proper name is "Hur" (חור).

20 The LXX transcribed this name as "A $\alpha \rho \omega v$ ”. Most of the Vulgata-manuscripts transcribed this name as Aaron (and not Aharon). Hebrew glottal fricative "hê" of the second syllable of the proper name seems to have been considered as a mater lectionis, because it appears transcribed into Latin with a vowel "a".

21 Note that the Hebrew-Latin-French dictionary of the thirteenth-century Hebrew Bible from Ramsey Abbey transcribes "het" (п) with an unvoiced glottal fricative "h", as for example דִהח "Dehe”; see OLSZOWy-Schlanger 2008, p. XXVIII. 
Latin "a” instead of Hebrew velar fricative "ḥet” ( $)$

"Rab Naaman” (רב נחמן) [San. 17a]:

Reference to Rab Naḥman (Hebrew "Rb Nḥmn”, רב נחמן).

"Rby Naamya” (רבי נחמיה) [San. 14a]:

This proper name in the corresponding Talmudic passage is Rabbi Nahamiâ (Hebrew "rby Nḥmyh”, רבי נחמיה).

Latin "zero" instead of Hebrew velar fricative "ḥet” (ח)

"Aggeus” [San. 11a]:

In Masoretic biblical Hebrew the name is "Haggay" (חָגֵ). The LXX usually tran-

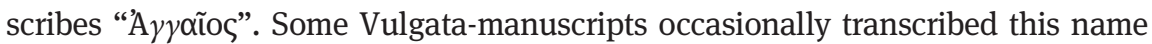
as “Aggaeus", but also "Aggeus”. Note how, in this case, Latin does not transcribe with the glottal fricative "h" the original Hebrew unvoiced fricative velar "het".

Faringal fricative “'ayin” (y)

As far as the Hebrew voiced faringal fricative "ayin” (ע) is concerned, note that the Latin Talmud transcribes this phoneme using either no specific phoneme, or a consonant " $h$ " (unvoiced glottal fricative), as manuscript B does:

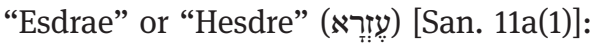

In Masoretic biblical Hebrew this anthroponym was vocalized as “Ezrā”" (עָזָזָרא).

\subsubsection{Sibilants}

Hebrew sibilants are rigorously transcribed in the Sanhedrin tractate, as in the following examples.

\subsubsection{Alveolar fricative "samekh" (ס)}

The Hebrew sibilant "samekh" is an alveolar fricative [s]. It was transcribed in the Latin translation of Sanhedrin with a consonant "c" (a voiceless alveolar fricative), as in the following two cases: ${ }^{23}$

22 Moreover, the Hebrew voiced alveolar fricative "zayin" was transcribed in Latin as "z" or with a voiced dentalized digraph "-sd-". Rabbinic Hebrew follows the biblical "textus receptus" ("zr",

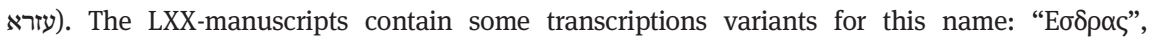

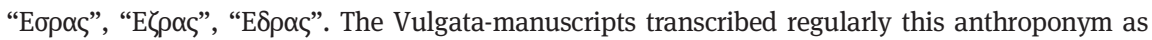
"Ezrae" or "Esdrae".

23 Note that in Sephardi Hebrew, but not in Ashkenazi Hebrew, there is always a phonetic distinction between $ת$ and $\delta$. 
"Rby Ioce” (רבי יוסי) [San. 39b]:

In the original Talmudic text, this rabbi is mentioned with his complete patronymic name: "Rabi Yôsê bar Hanîna"” (רבי יוסי בר חנינא).

“Cenhezerim” or “Cenhezrim” (סנהדרין > Greek “ouvÉSpıv”) [San. 17a]:

Reference title of the Talmudic tractate of Sanhedrin (see San. 17a). ${ }^{24}$ Note that the initial Hebrew sibilant "samekh" is an unvoiced alveolar fricative [s].

Postalveolar fricative "šin" (ש)

The Hebrew unvoiced postalveolar fricative "šin" (ש) is transliterated in the Latin Sanhedrin as "s" or "ss", as in the following examples:

"Rby Symeon" (רבי שמעון) [San. 14a]:

This rabbi in the original passage of the Babylonian Talmud appears as "rby šm wn" (רבי שמעון), i. e. "Rabbi Šimeeôn".

"Cezer nassym” (סדר נשים) [San. 20b]:

Reference to Seder Našîm, the third order of the Talmud containing the laws related to women and family life.

\subsubsection{Alveolar fricative "zayin" ( $($ )}

As far as the Hebrew voiced alveolar fricative "zayin" is concerned, note that this consonant is transcribed in Latin with a grapheme " $z$ " or with a voiced dentalized digraph “-sd-", as we can see in the following example:

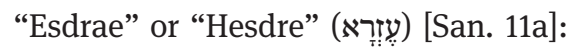

Note that in Masoretic biblical Hebrew this anthroponym was vocalized as

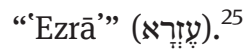

24 In the preface to the Extractiones de Talmud, one can find a definition of this term: "[20] Cenhezerim, id est ordinatores .LXX.; sunt iudices qui instituebantur ad illorum formam, quos perfecit Moyses ad consilium Iethro".

25 It is interesting to note here that "'ayin” (y) in Ashkenazi Hebrew is completely silent at all times, whereas in Sephardi Hebrew it is realized as a phoneme. This specific sound varies between communities. Regarding the Hebrew-Latin-French dictionary of Ramsey Abbey, the Latin transcriptions of "“ayin" are with "h”, as for example בעט - "Behet" and דע - "Dah", or without any specific phoneme, as for example בער - "Baer see OlszowySCHLANGER 2008, p. XVIII. 


\subsubsection{Plosives}

Regarding the consonantic plosive series, it is interesting to note that the articulation of the plosives in the Latin transcription of Sanhedrin usually follows the Masoretic rules of fricatization of the occlusive series "bgdkft" in an intervocalic context, as is shown by the following examples:

\subsubsection{Bilabial plosive “bet” (ב)}

The Hebrew voiced bilabial plosive "bet" in an intervocalic context becomes a voiced labiodental fricative and is transliterated into Latin with a "v" grapheme (voiced labiodental fricative), as in the following cases:

“Avozazara” (עבודה זרה) [San. 7a]:

Hebrew "Abôdâ Zarâ", the Talmud tractate in Seder Nezîqîn on the idolatry. ${ }^{26}$

\subsubsection{Occlusive velar "gimmel" (ג)}

The Hebrew voiced occlusive velar "gimmel" is transcribed in the Latin translation of Sanhedrin with the trigraph "gui", which ultimately represents the sound of a voiced velar plosive. Note that, to transcribe the voiced plosive velar [g], the Talmud translator uses "gui" and not "gi" (as one would expect for classic Latin), probably influenced by the vernacular (Old French?).

"Macecta guityn" [San. 20b]:

Reference to the Talmudic tractate of Gîțîn (גיטין), literally 'documents', a tractate connected with the kind of document known as "get", related to divorce documents.

\subsubsection{Alveolar plosive “dalet” (ד)}

The Hebrew voiced alveolar plosive “dalet” (ד) is transliterated into Latin as " $z$ ", a grapheme that probably represents a dentalized fricative alveolar, as we can see in the following examples: ${ }^{27}$

\footnotetext{
26 Note the regressive assimilation of the voiced plosive dental "dalet" for a voiced alveolar fricative "zayin".

27 Compare this phenomen with the trend in Ashkenazi Hebrew to pronunce $ת$ as $[\mathrm{s}]$, like for example in "šabbos" vs. "šabbat".
} 
"Rby Huza” or "Huca” (רבי יהודה) [San. 4b(1)]:28

In the Babylonian Talmud this rabbi was mentioned with his whole patronymic name as Rabbi Yehudâ ben Têmâ, "rby yhwdh bn tym”" (רבי יהודה בן תימא).

“Cezer nassym” (סדר נשים) [San. 20b]:

Reference to Seder Našîm (סדר נשים), the third order of the Talmud containing the laws related to women and family life.

\subsubsection{Velar plosive “kaf” (つ)}

In an intervocalic context, the original Hebrew velar plosive "kaf" (כ) [k] becomes a velar fricative [x], written in Latin as "ch" (a digraph that represents a voiceless velar fricative $/ \mathrm{x} /$ ). Note that by spelling Latin "ch", the articulation of Hebrew "kaf" (fricative intervocalic plosive) follows indeed the Masoretic rule of the fricative articulation of "bgdkft", as we can see in the following examples:

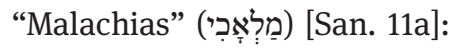

In Masoretic biblical Hebrew this theophoric anthroponym was vocalized as

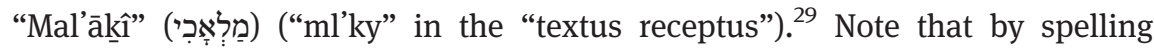
Latin "ch", the fricative articulation of the intervocalic fricative velar "kaf" (Masoretic rule of the fricatization of "bgdkft") is marked.

“Zacharias” (זָכְרְיָָ) [San. 11a]:

Theophoric biblical anthroponym. In Masoretic biblical Hebrew it was vocalized

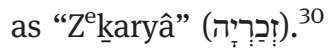

28 Note that Latin "Huza" corresponds to Hebrew "Yehudâ": the first syllable of the name has been apocopated, whereas Hebrew "d" (alveolar plosive) was transcribed with "z" (or even "c" in manuscript C).

29 The LXX-version transcribes this anthroponym as "M $\alpha \lambda \alpha \chi i \alpha \varsigma^{\prime}$ " (although in I Esr 9, 44 it is

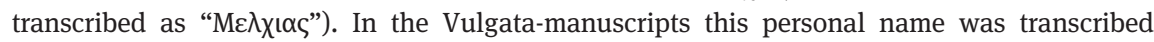
usually as "Malachiae" or "Malacia" (see Mal 1, 1).

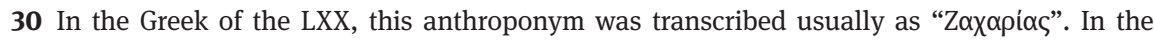
Vulgata-manuscripts it was cited as "Zaccharias" or "Zacharias". Regarding the tractate Sanhedrin, the Latin Talmud follows once again the onomastic tradition of the Vulgata as far as the transcription of this name is concerned. Note that by spelling Latin "ch", the fricative articulation of the intervocalic fricative plosive "kaf" is marked, following the Masoretic rule of the fricatization of "bgdkft". 


\subsubsection{Bilabial plosive “pe” (פ)}

The Hebrew bilabial plosive "pe" (פ) can be transcribed in the Latin Talmud tractate of Sanhedrin as an unvoiced labiodental fricative " $\mathrm{f}$ " in an intervocalic context:

"Rbi Tharfon" (רבי טרפון) [San. 33a]:

In the original Talmudic passage, this rabbi appears as "Rabbi Ṭarfôn" (רבי טרפון).

Nevertheless, Hebrew “p” (פ) can be transcribed also as a bilabial plosive, for those proper names of a non-semitic or onomatopeic origin, as one can see in the following examples:

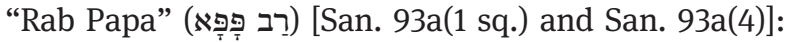

In the original Talmudic passage, this rabbi appears as “Rab Pappa” (רֵ פָָָּּּ).

“Rbi Papiath”/"Papyam” (רבי פפייס/רבי פפיס) [San. 94a(3)]:

In the original Talmudic passage, this rabbi is mentioned as "Rabbî Papyâs"

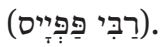

\subsubsection{Plosive alveolar "tav" (ת)}

The Hebrew voiceless plosive alveolar "tav" $(\Omega)$ is transcribed in Latin with the digraph "th", an unvoiced alveolar plosive, as one can see in the following example:

“Rby Jonathan” or "Ionathan” (רבי יונתן) [San. 39b]:

רבי (ר) (יונתן. ${ }^{31}$

\subsubsection{Dentals}

\subsubsection{Emphatic plosive alveolar "tet" (ט)}

The Hebrew consonant "tet" (ט), an emphatic unvoiced plosive alveolar phoneme (a consonant that in origin was velarized or faringalized, as it was in Arab,

31 It is interesting to note that $\boldsymbol{\Omega}$ is pronounced [s] in Ashkenazi Hebrew, whereas in Sephardi Hebrew $\Omega$ - a dental plosive - is pronounced as [t]. In Sephardi Hebrew there is always a phonetic distinction between $\Omega$ and $\delta$. 
or postglotalized, as it was in Ethiopic $/ \mathrm{t}$ '/) is transcribed in Latin as "th" or " $\mathrm{t}$ " (i. e. unvoiced plosive alveolar), as one can see in the following example:

"Rbi Tharfon" or "Tarphon" (רבי טרפון) [San. 33a]:

In the original passage of the Hebrew Babylonian Talmud, this rabbi appears as "Rabbi Tarfôn" (רבי טרפון).

\subsubsection{Plosive alveolar "tav" (ת)}

The Hebrew voiceless plosive alveolar "tav" (ת) is transcribed in the Latin tractate of Sanhedrin with a digraph "th", an unvoiced alveolar plosive, as one can see in the following example:

“Rby Jonathan” or "Ionathan” (רבי יונתן) [San. 39b].

\subsubsection{Alveolar plosive “dalet” (ד)}

The Hebrew voiced alveolar plosive "dalet” (ד) is transliterated into Latin as " $z$ ", a grapheme that probably represents a dentalized fricative alveolar: ${ }^{32}$

"Rby Huza” (רבי יהודה) [San. 4b(1)]:

In this Talmudic passage of Sanhedrin, this rabbi is mentioned with his whole patronymic as Rabby Yehudâ ben Temâ, "rby yhwdh bn tym’” רבי (יהודה בן תימא.).

“Cezer nassym” (סדר נשים) [San. 20b]:

Reference to Seder Našîm (סדר נשים), the third order of the Talmud containing the laws related to women and family life.

\subsubsection{Postalveolar affricate "șade" (y)}

The Hebrew consonant "șade" (unvoiced africate postalveolar [t $\mathrm{f}]$ ) is transcribed in the Latin Talmud (Sanhedrin) in a simplified way as "s", i. e. as an unvoiced fricative alveolar, as in the following example:

"Rby Ysaac" or "Isaac" (יצחק) [San. 21b]:

In the Hebrew Talmudic passage this anthroponym is cited as "Rabbi Yiṣhaq" (רבי יצחק).

32 Note that, in this case, the alveolar pronunciation of $\mathrm{T}$ in " $\mathrm{z}$ " can be explained because of the alveolar pronunciation of $/ \mathrm{t} /$ and $/ \mathrm{d} /$ in Ashkenazi Hebrew. In Sephardi Hebrew $ת$ and $\mathrm{T}$ are dentalized. 


\subsubsection{Anthroponyms}

As a norm, in the Talmudic tractate of Sanhedrin, the biblical proper names are transcribed following the Vulgata and not the reading offered by the "textus receptus masoreticus", as one can see in the following examples:

“Aggeus” (חַבג) [San. 11a]

Regarding this biblical personal name, the Latin Sanhedrin does not transcribe the original Hebrew fricative velar unvoiced "het" with the glottal fricative "h". As we have already seen, in biblical Masoretic Hebrew this personal name is "Haggay" (חָג), because the reading is not the Masoretic one, but that of the Vulgata, where this anthroponym was transcribed as “Aggaeus" or "Aggeus”, depending on the manuscripts. ${ }^{33}$

“Heldad", also "Helaad" or "Heldat” (אֶלְדָד) [San. 17a]

As we have seen, in Masoretic biblical Hebrew the name of this prophet was vocalized as “'Eldād” (אֶלָדָד, Nm 11, 26 sq.). In rabbinic Hebrew (San. 17a), this name was also written as "'Eldad” (Hebrew “'ldd”, אלדד). In the Latin version of the Vulgata, this name was transliterated as "Heldad".

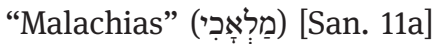

Regarding this theophoric biblical anthroponym, most of the Vulgata-manuscripts transcribed this anthroponym as "Malachiae" or "Malacia" (see Mal 1, 1; in Masoretic biblical Hebrew this theophoric personal name was vocalized

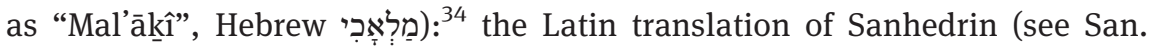
11a) follows once again the transcription of the Vulgata to transcribe this name. ${ }^{35}$

“Medad", also "Medat” (מידָד) [San. 17a]

A biblical prophet. In Masoretic biblical Hebrew this anthroponym was vocalized as "Mêdād" (מידָד, Nm 11, 26 sq.). Rabbinic Hebrew follows the "textus receptus", when writing this name as "Mydd" (מידד). The LXX transcribed it as "M $\omega \delta \alpha \delta$ "

33 In the LXX, this anthroponym was transcribed as "Ayyoĩos". Note that, in order to transliterate the plosive glottal "aleph" from Hebrew into Latin, a glottal fricative "h" was used.

34 Whereas the "textus receptus" writes "Ml'ky". The LXX reads this personal name as

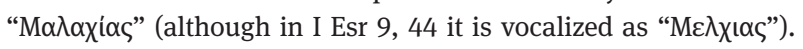

35 Note that through the "ch" Latin grapheme is noted the intervocalic fricative articulation of Hebrew plosive "kaf". 
(reading perhaps a "waw" - Greek $\omega$ - instead of a "yod"), whereas in the Latin version of the Vulgata this name was translated as "Medad". 36

“Moyses" (משֶׁה) [San. 5b]

Biblical and rabbinic personal name. In Masoretic biblical Hebrew it was vocalized

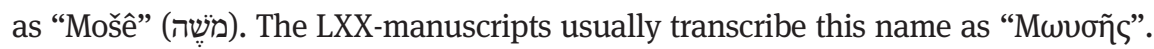
In the Latin Vulgata-manuscripts this proper name appears as "Moses", but also as "Moyses". The Latin translation of the Talmud, once again, follows the onomastic tradition of the Vulgata in its onomastic transcription.

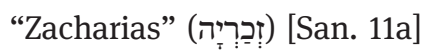

In Masoretic biblical Hebrew this theophoric biblical name was vocalized as

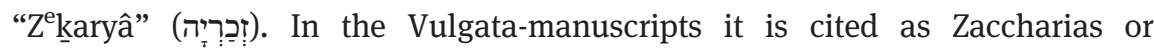
Zacharias. Regarding the Sanhedrin tractate (San. 11a[1]), the Latin Talmud follows once again the onomastic tradition of the Vulgata regarding the transcription of this name. ${ }^{37}$

\subsubsection{Toponyms}

Like in the case of anthroponyms, the Latin translation of Sanhedrin transcribes the biblical toponyms according to the Latin tradition of the Vulgata and not according to the reading of the "textus masoreticus", as one can see in the following examples:

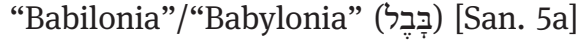

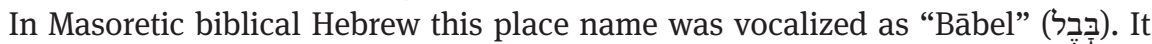
was transcribed in the Greek of the LXX-manuscripts as "B $\alpha \beta v \lambda \tilde{\omega} v i \alpha$ ". In the Vulgata Stuttgartensia edition, this toponym was edited as "Babylonia" (not "Babilonia” nor "Babillonia”).

The Latin transcription of this toponym in the tractate of Sanhedrin (San. 5a, San. 24a and San. 24a), thus, follows once again the onomastic tradition from the LXX and Jerome.

“Iuda" (יהוּדָהד) [San. 5a]

Another biblical toponym. In Masoretic biblical Hebrew it was vocalized as "Yehûdâ" (יהוּ:דi:).

36 Note the trend of some Romance languages, as Catalan, Occitan and also probably Old French, to pronounce a voiced dental [d] at the end of a word with an unvoiced dental [t].

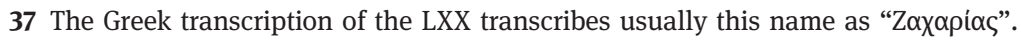




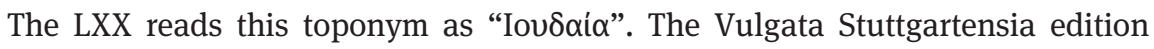
writes "Iuda" (although in some manuscripts one can find "Iudea", following the LXX-version, cf. Is 1, 1). In this case, the Latin Talmud translation (San. 5a) follows once again the onomastic Latin biblical tradition.

\subsubsection{Biblical and Talmudic realia}

Biblical and Talmudic Hebrew and Aramaic terms transcribed into Latin characters appearing throughout the Latin Talmud inform us about how they were articulated in the medieval Hebrew (thirteenth century) of the translator(s). ${ }^{38}$

\section{“Avozazara” (Hebrew עבודה זרה) [San. 7a]}

This tractate of the Talmud belonging to Seder Nezîqin is the phonetic transcription of Hebrew “"Abôdâ Zarâ” (עבודה זרה), 39 the Talmud tractate (Seder Nezîqîn, סדר נזיקין) on idolatry (here, there is a regressive assimilation of the original dental plosive voiced "dalet" for the fricative aleveolar voiced "zayin").$^{40}$ Regarding the transcription of "dalet" in " $z$ ", as we have already seen, it is interesting to note that there is a tendency in Ashkenazi Hebrew to pronounce the dentals $ת$ and 7 more alveolar than dental plosive, in contrast to the pronunciation of the Sephardi tradition.

"Bezgoria”, also "hezgazya”, "bezgazia” or "bezgazia” (Hebrew בית גוריה) [San. 11a] Latin Talmudic reference to Hebrew "byt gwryh” (בית גוריה), 'house of Gurya', in Jericho (see San. 11a).

“Cenhezerim”, also “Senhezerim” and “Cenhedrym” (Hebrew סנהדרין) [San. 17a]

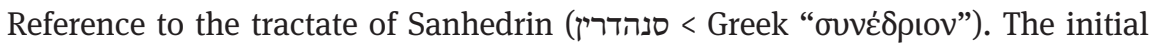
Hebrew sibilant "samekh" is an unvoiced fricative alveolar [s]: note that in Latin it was transcribed with a "c" or "s". 41

38 An interesting study on Talmudic Hebrew realia and French glosses in Paris, Bibliothèque nationale de France, Ms. lat. 16558 is found in MerchaviA 1966, p. 189-198.

39 This term appears also explained in the preface to the Latin Talmud: [17] “'Avozazara' idem est quod servicium peregrinum seu cultus extraneus, quod ydolatria vel secundum apostolum 'ydolorum servitus' appellatur. Quandoque vero sumitur pro ipso cultu divino creature exhibito, quandoque [vel] pro illis, quibus exhibetur, ut sunt sancti et ipsorum ymagines, quandoque pro rebus in quibus vel per quas exhibetur, sicut est thus et panis et vinum et vasa et ornamenta et omnia sacramenta et sacramentalia ecclesie; quandoque pro locis, ut sunt ecclesie et cimiteria, de hiis reperies in sequentibus exempla".

40 Note also that, as it happens within an intervocalic context in Masoretic Hebrew, the voiced Hebrew bilabial plosive "bet" is fricatized for a voiced labiodental "v" in Latin.

41 Note also that the sufix "-im" in the Latin translation of the tractate, instead of the suffix ending "-in”, could indicate an Hebraization of this proper name. 


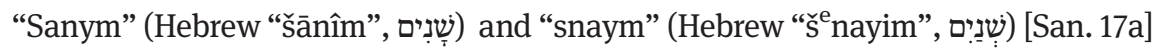
Regarding both Hebrew substantives, note that the Latin translation of Sanhedrin distinguishes masoretically between the two Hebrew substantives, formally differentiated by specific vocalisation: "šānîm” (plural שִָָׁ singular

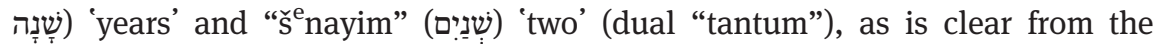
following passage of Sanhedrin [17a]:

Dicit rab Naaman: Quid est quod scriptum est: 'Tu ergo ille es de quo locutus sum in diebus antiquis in manu servorum meorum prophetarum qui prophetaverunt in diebus illorum temporum - hebraeus annorum -' [Ez 38, 17]. Non dicas 'sanym' - id est annorum - sed 'snaym' - id est duorum -. Hii fuerunt Heldad et Medad qui prophetaverunt tempore Moysi: hii sunt dies antiqui. ${ }^{42}$

“Thale", also "thalem” or "thalez" (Hebrew טِלִית) [San. 20b]

In the Latin Talmud of Sanhedrin (20b[4]), the hebraism "thale", as a semitic loanword in the Latin translation, appears as a transcription of Hebrew "tallitt"

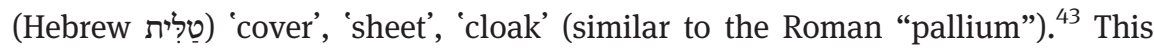
Hebrew loanword was probably used to translate the suffixed Hebrew גונדו, "his cloak', ${ }^{44}$ into Latin "suum 'thale", 45

42 I cite here the editio critica, in preparation by Ulisse CECINI/ÓsCAR DE LA CRUZ PALMA. Cf. Talmud Bavli. Sanhedrin, 1, fol. $17 \mathrm{a}^{2}$ :

רב נחמן אמר על עסקי גוג ומגוג היו מתנבאין שנאמר כה אמר ה' אלהים האתה הוא אשר דברתי בימים קדמונים ביד

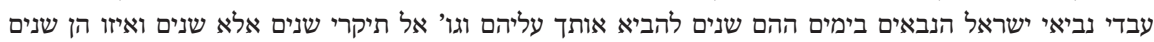
נביאים שנתנבאו בפרק אחד נבואים בימים אחת הוי אומר אלדד ומידד

English translation: 'Rab Naḥman said: It was concerning Gog and Magog that they prophesied, as it is stated: Thus says the Lord our God: Are you [Gog] the one about whom I spoke in ancient days through My servants, the prophets of Israel, who prophesied in those days, years ago, [that I was going] to bring you against them etc? [Ez 38, 17] Do not read this as it is written, read it as if it were written, two.'

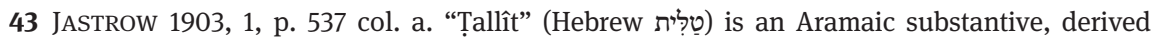
from de Aramaic verb "țll”, 'to cover', 'to screen', ibid. The ashkenazi and yiddish pronuntiation of this word was "tallis" or "tales" (plural "talesim"), whereas the old sephardic pronunciation of the noun could have been "talet" or "taled", see TARGARONA BORRÀS 1995, p. 459.

44 Cf. Talmud Bavli. Sanhedrin, 1, fol. 20b ${ }^{4}$ :

ולבסוף לא מלך אלא על מטתו שנאמר הנה מטתו שלשלמה וגו' ולבסוף לא מלך אלא על מקלו שנאמר זה היה חלקי מכל עמלי רב ושמואל חד אמר מקלו של משלו וחד אמר גונדו

English translation: 'And eventually he reigned only over his staff, as it is stated: 'This was my reward for all my endeavors.' Rav and Smuel disputed what the word 'this', an allusion to the sole remnant of Solomon's dominion, means: One said that it means his staff, and the other one said that it means his cloak.'

45 Cf. Extractiones de Talmud [San. 20b(4)] (Paris, Bibliothèque nationale de France, Ms. lat. 16558, fol. 147vb-148ra): “... 'En lectulum Salomonis .LX. fortes ambiunt etc.' [Ct 3, 7] In fine 


\section{Conclusion}

We have presented here an overview of the most important onomastic and phonetic transcription features that can be found in the Latin translation of Sanhedrin, regarding the transcription of proper names and their transmission.

As far as the onomastic features are concerned, we have pointed out that the Latin Talmud has inherent difficulties - due to the Latin vernacular (Old French) and Latin language - to transcribe biblical proper names, especially regarding the transcription of guttural and emphatic consonants, although some phenomena in the Latin transcription as well as some remarks that are in the preface to the Extractiones inform us that the translator(s) had profound knowledge of the Masoretic Hebrew grammar.

It is also interesting to note that many of the biblical realia in Sanhedrin are transcribed as if they had been heard orally, because there is a large number of linguistic phenomena (assimilations, etc.), which can only be explained through orality. This fact may indicate that the translation of the original Talmudic text was at least at times an oral process.

With regard to the use of biblical and Talmudic texts, we see that in terms of Sanhedrin, the Latin translation usually is close to the original Hebrew 'Vorlage', except in the case of the personal proper names of the rabbis (which are usually omitted or abbreviated). As far as the biblical proper names of the Latin Talmud are concerned, one can see a clear trend: the biblical anthroponyms and toponyms usually follow the Vulgata version. ${ }^{46}$

Finally, it is interesting to remark that in the Latin transcription of Sanhedrin one can observe trends belonging to the tradition of Ashkenazi Jewish, for example no pronunciation of $\nu$, but pronunciation of $\Omega$ as [s], as

non fuit rex nisi super baculum suum - quia sicut dicit glossa Salomonis: Asmosay id est Asmodeus rex demonum expulit eum de sede sua, sicut legitur in cezer nassym in macecta

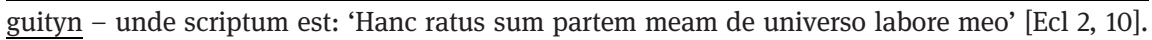
Hoc fuit baculus quem tenebat in manu sua. Alius dicit quod fuit concha ipsius cum qua bibebat aquam. Alius dicit quod fuit suum thale - pallium stamineum quo utebatur in synagoga." Note, however, that regarding the modern editions of Sanhedrin (20b[4]) the word for "cloak' is not "thale", but "gunda"” (suf. "gwndw"): רב ושמואל חד אמר מקלו וחד אמר גונדו. The word "gunda” (גוּנְָּּא), 'cloak', is derived from rabbinic Hebrew (perhaps an Aramaic loanword?). 46 The same happens regarding direct biblical quotations in Sanhedrin. As far as this issue is concerned, one can see a clear trend: the biblical quotes usually read the Vulgata version, but in those cases where, for a good understanding of the Talmudic text it is necessary to read literally the original Hebrew or Aramaic text, the Latin translator has no problem to translate literally the "textus receptus". Regarding the question of Rashi's biblical commentaries on the Latin Talmud, see HASSELHOFF 2015. 
well as to the Hebrew Sephardic tradition, for example the phonetic distinction between $ת$ and $\delta$.

On the one hand, this last-mentioned trend must be seen against the backdrop that the Jews of Northern and Eastern France had strong cultural ties with the Jews of Western Germany (Ashkenaz). But on the other hand, as the Hebrew of Rashi and French authors of Tosafot shows, the mother tongue is Old French, not Middle High German, although it is close to Ashkenazi Hebrew concerning its sources.

\section{Abbreviation}

CChr.CM Corpus Christianorum. Continuatio Mediaevalis

\section{Bibliography}

\section{Texts}

\section{Biblia Hebraica}

Biblia Hebraica, ed. KARL Elliger/Wilhelm Rudolph: Biblia Hebraica Stuttgartensia ..., Stuttgart ${ }^{5} 1997,1-1574$.

LXX

Septuaginta, ed. Alfred Rahlfs: Septuaginta. Id est Vetus Testamentum graece iuxta LXX interpretes, Stuttgart 1979 [1935], 1-941.

Talmud Bavli. Sanhedrin

Talmud Bavli. Sanhedrin, ed./trad. JeRome SCHOtTENSTEIN: Talmud Bavli 47-49: Tractate

Sanhedrin 1-3, Brooklyn (NY.) 1993-1995 (etc.).

Vulgata

Biblia Vulgata, ed. Roger GRYSON e. a.: Biblia sacra iuxta vulgatam versionem, Stuttgart ${ }^{4} 1994$ [1969], 3-1976.

\section{Studies}

\section{ALTANER 1933}

Berthold Altaner: "Zur Kenntnis des Hebräischen im Mittelalter", in Biblische Zeitschrift 21 (1933) 288-308.

BARNETT 1971

Sephardi heritage. Essays on the history and cultural contribution of the Jews of Spain and Portugal 1: The Jews in Spain and Portugal before and after the expulsion of 1492, ed. by RICHARD DAVID BARNETT, London 1971. 


\section{CECINI e. a. 2015}

ULISSE CECINI e. a.: “Observacions sobre la traducció llatina del Talmud (París, med. s. XIII)", in Tamid 11 (2015) (in press).

CHAZAN 2012

ROBERT CHAZAN: “Trial, condemnation, and censorship. The Talmud in medieval Europe", in The Trial of the Talmud 2012, 1-92.

DAHAN 2007

GILBERT DAHAN: Les intellectuels chrétiens et les juifs au Moyen Âge (Patrimoines.

Judaïsme), Paris 2007 [Paris 1990].

DAHAN/NiCOLAS 1999

Le brûlement du Talmud à Paris 1242-1244, ed. by GILBERT DAHAN/ÉLIE Nicolas (Nouvelle Gallia Judaïca [1]), Paris 1999.

FIDORA 2014

AleXANDer Fidora: “The Latin Talmud and its influence on Christian-Jewish polemic", in Journal of Transcultural Medieval Studies 1 (2014) 337-342.

FIDORA 2015a

AleXANDeR Fidora: "Die Handschrift 19b des Arxiu Capitular de Girona. Ein Beitrag zur Überlieferungsgeschichte des lateinischen Talmud”, in a Festschrift, Bochum 2015 (in press). FIDORA 2015b

AleXANDER Fidora: "The Latin Talmud and its translators. Thibaud de Sézanne vs. Nicholas Donin?", in Henoch. Historical and Textual Studies in Ancient and Medieval Judaism and Christianity 37 (2015) 17-28.

FIDORA 2015C

ALEXANDER FIDORA: "Textual rearrangement and thwarted intentions. The two versions of the Latin Talmud”, in Journal of Transcultural Medieval Studies 2 (2015) 63-78.

FISHMAN 2011

TALYA FISHMAN: Becoming the people of the Talmud. Oral Torah as written tradition in medieval Jewish cultures (Jewish Culture and Contexts), Philadelphia (Pa.) 2011.

FRIEDMAN 2012a

JOHN FRIEDMAN: "The dirge of Rabbi Meir of Rothenberg on the burning of the Talmuds of thirteenth-century France by king Louis IX”, in The Trial of the Talmud 2012, 169-172.

FRIEDMAN 2012b

John FrIedman: “The disputation of Rabbi Yehiel of Paris", in The Trial of the Talmud 2012, 126-168.

GARBELL 1954-1956

IRENE GARBELL: “The pronunciation of Hebrew in medieval Spain”, in Homenaje MillásVallicrosa 1954-1956, 1, 647-696.

HASSELHOFF 2015

GÖRGE K. HASSELHOFF: "Rashi for Latin readers. The transliterations of Paris, 1240, with an edition of the excerpts from Leviticus, Numbers, and Deuteronomy”, in HASSELHOFF/ STÜNKEL 2015, 103-109.

HASSElhoff/de LA CRUz PALMA 2015

Görge K. HASSELhoff/ÓSCAR DE LA CRUz [PALMA]: “Ein Maulbronner Fragment der lateinischen Talmudübertragung des 13. Jahrhunderts (mit Edition)”, in Zeitschrift für Württembergische Landesgeschichte 74 (2015) 331-344 [with 2 figures]. 


\section{HASSELHOFF/STÜNKEL 2015}

Transcending words. The language of religious contact between Buddhists, Christians, Jews, and Muslims in premodern times, ed. by GöRGE K. HASSELHOfF/KNUt MARTIN StünKEL, Bochum 2015.

HOFF 2012

Jean Connell Hoff: "The Christian evidence", in The Trial of the Talmud 2012, 93-126. Homenaje Millás-Vallicrosa 1954-1956 Homenaje a Millás-Vallicrosa 1-2, Barcelona 1954-1956.

JASTROW 1903

MARCUS JASTROW: A dictionary of the Targumim, the Talmud Babli and Yerushalmi, and the Midrashic literature 1-2, New York 1903 (etc.).

KLAPPER 1926

JOSEPH KLAPPER: “Ein Florilegium Talmudicum des 13. Jahrunderts", in Literaturwissenschaftliches Jahrbuch der Görres-Gesellschaft 1 (1926) 3-23.

KLIBANSKY 1933

ERICH KLIBANSKY: "Zur Talmudkenntnis des christlichen Mittelalters", in Monatsschrift für Geschichte und Wissenschaft des Judentums 77 (1933) 456-462.

LOEB 1880-1881

ISIDORE LOEB: “La controverse de 1240 sur le Talmud”, in Revue des études juives 1 (1880) 247-261; ibid. 2 (1881) 248-270; ibid. 3 (1881) 39-57.

MACCOBY 1982

HYAM MACCOBY: Judaism on trial. Jewish-Christian disputations in the

Middle Ages (The Littman Library of Jewish Civilization), Rutherford (NJ.)/London 1982 (etc.).

MARTIN/VEZIN 1990

Mise en page et mise en texte du livre manuscript, ed. by HeNRI-JEAN MARTIN/JEAN VeZIN, Paris 1990.

MERCHAVIA 1965-1966

Chenmelech MerchaviA: "Latin translations in the margins of the Talmud manuscript Florence and the manuscript Paris, 16558", in Kiryat Sefer 41 (1965-1966) 543-556 [Hebrew].

MERCHAVIA 1966

Chenmelech Merchavia: "Talmudic terms and idioms in the Latin manuscript Paris B.N. 16558”, in Journal of Semitic Studies 11 (1966) 175-201.

MERCHAVIA 1970

Chenmelech MerchaviA: The Church versus Talmudic and Midrashic literature (500-1248), Jerusalem 1970 [Hebrew].

MILLÁS VALLICROSA 1960

José María Millás Vallicrosa: "Extractos del Talmud y alusiones polémicas en un manuscrito de la Biblioteca de la Catedral de Gerona”, in Sefarad 20 (1960) 17-49.

OLSZOWY-SCHLANGER 2008

JUDith OLSZOWY-SCHLANGER e. a. (ed.): Dictionnaire hébreu-latin-français de la Bible hébraïque de l'abbaye de Ramsey (XIII ${ }^{e}$ s.) (CChr.CM. Lexica Latina Medii Aevi 4), Turnhout 2008.

PÉREZ FERNÁNDEZ 1992

Miguel PÉrez Fernández: La lengua de los sabios 1: Morfosintaxis (Biblioteca midrásica 13), Estella 1992. 


\section{Rose 2011}

PAul LAUREnCE Rose: "When was the Talmud burnt at Paris? A critical examination of the Christian and Jewish sources and a new dating. June 1241", in Journal of Jewish Studies 62 (2011) 324-339.

\section{SARNA 1971}

NAHUm MATtATHIAS SARnA: "Hebrew and Bible studies in medieval Spain”, in BARNETT 1971, 323-368.

SIRAT 1990

ColetTe SiRAT: “Le premier Talmud complet”, in MARTIN/VeZIN 1990, 184-188.

SIRAT 1991

Colette SiRat: “Le livre hébreu en France au Moyen Âge”, in Michael. On the History of the Jews in the Diaspora 12 (1991) 299-336.

TARGARONA BORRÀS 1995

JUDIT TARGARONA BORRÀS: Diccionario hebreo-español. Bíblico, rabínico, medieval y moderno, Barcelona 1995.

The Trial of the Talmud 2012

The Trial of the Talmud. Paris, 1240. Hebrew texts translated by JOHN FRIEDMAN. Latin texts translated by Jean Connell Hoff. Historical essay by ROBERT CHAZAN (Mediaeval Sources in Translation 53), Toronto 2012.

Note: This paper was prepared in the context of the project 'The Latin Talmud and Its Influence on Christian-Jewish Polemic', funded by the European Research Council (FP7/2007-2013)/ERC Grant agreement $n^{\circ} 613694$. 